\title{
EVALUATING THE MANAGEMENT SUCCESS OF AN ALIEN SPECIES THROUGH ITS HUNTING BAGS: THE CASE OF THE SIKA DEER (CERVUS NIPPON) IN THE CZECH REPUBLIC
}

\author{
Laura Saggiomoํㅜ Bruno Esattore ${ }^{2,3}$, Luděk Bartoš2,3 \\ ${ }^{1}$ Faculty of Forestry and Wood Sciences, Czech University of Life Sciences Prague, Kamýcká 129, 16500 \\ Praha 6-Suchdol, Czech Republic \\ ${ }^{2}$ Department of Ethology, Institute of Animal Science, Přátelství 815, 10400 Praha 10-Uhříněves, Czech Republic \\ ${ }^{3}$ Department of Ethology and Companion Animal Science, Faculty of Agrobiology, Food and Natural Resources, \\ Czech University of Life Sciences Prague, Kamýcká 129, 16500 Praha 6-Suchdol, Czech Republic
}

Link to this article: https://doi.org/10.11118/actaun.2021.030

Received: 15. 11. 2020, Accepted: 18. 4. 2021

To cite this article: SAGGIOMO LAURA, ESATTORE BRUNO, BARTOŠ LUDĔK. 2021. Evaluating the Management Success of an Alien Species Through Its Hunting Bags: The Case of the Sika Deer (Cervus Nippon) in the Czech Republic. Acta Universitatis Agriculturae et Silviculturae Mendelianae Brunensis, 69(3): 327-336.

\begin{abstract}
Alien mammal species have a very long history of anthropogenic introductions and have been extensively studied due to their severe impact on native biodiversity and ecosystems. One of the most detrimental species is the sika deer (Cervus nippon), a native Asian deer that has settled in several districts of the Czech Republic and has widely colonized the area with increasing population numbers. In this study we aimed to investigate the trend of the number of sika deer culled in the country between 1994 and 2018, and to highlight limits and flaws in the current management and hunting strategy. We identified three hunting subpopulations based on both the official hunting records and the environmental and urban features of the Czech Republic. The analyses of the subpopulations over the period between 1994 and 2018 revealed very different trends, some of which are alarming. The average annual increase in culling was 7.4\% for Subpopulation 1 (SP1), 1\% for Subpopulation 2 (SP2), and 3.7\% for Subpopulation 3 (SP3). Considered the increased percentages of culled deer, and the environmental features of the country, we evaluated the central subpopulation (SP2) as the easiest to manage due to its small area of extension, the scarcity of forested regions and, as possible contribution, the natural occurrence of predators. Being the other two subpopulations spread across larger forested areas and hosting a higher number of deer, we concluded that an increasing effort, and a more well-designed strategy to ensure accuracy of hunting plans seems to be impelling for the country.
\end{abstract}

Keywords: sika deer, game management, Czech Republic, alien species, G.I.S

\section{INTRODUCTION}

Among today's most alarming environmental threats, alien species have a prominent role (Mooney, 2005). Along with the severe impacts on native biodiversity and ecosystems, they also cause considerable economic damages (Mooney, 2005; Nentwig, Kühnel et al., 2010), and their spreading severely affects the natural patrimony and the well-being of the citizens (McNeely, 2001). Amidst the high number of alien species, mammals have a very long history of anthropogenic introductions and, being the most studied class, they are also known in-depth, as their biology has been extensively explored (Genovesi, Bacher et al., 2009). 
Nevertheless, their management stays challenging, due to the great differences among the impacts of the different species (Nentwig, Kühnel et al., 2010). Enlisted as one of the most ubiquitous and deleterious alien mammals in Europe (Genovesi, Bacher et al., 2009), being also included in the "Technical support to EU strategy on invasive alien species (IAS)" (Kettunen, Genovesi et al., 2009) and in the "DAISIE database" (Roy and Hulme, 2008), the sika deer (Cervus nippon) was introduced to the continent about 150 years ago, along with many other exotic plants and animals both as an addition to the local flora and fauna and as new available game species (Bartoš, 2009) and rapidly spread (Bartoš, 2009; Genovesi, Bacher et al., 2009).

In the Czech Republic, the first sika were released in 1891 into the Kluk enclosure near Poděbrady, and many other have been imported and released in gardens and parks (Kokeš, 1970) in the following years, until the beginning of the $20^{\text {th }}$ century. The animals remained enclosed until when, during WWII, fences were destroyed, and sika escaped (Vavruněk, 1977). Since then, the number of sika deer in the country has rapidly increased (Dvořák and Palyzová, 2016; Hanzal et al., 2017), along with the harms to the ecosystem caused by the species (Hanzal et al., 2017). Sika deer in the Czech Republic are recognised as a source of damages for both the vegetation and for the native red deer (Cervus elaphus), with which hybridization occurs (Bartoš, 1981, 1993, 2009; Krojerová-Prokešová, Barančeková et al., 2017). Nowadays, as it is possible to read in the official guideline documents for the game management in the Czech Republic accessible via the Ministry of Agriculture of the Czech Republic website, sika are among the 19 mammals and the 9 ungulates that can be legally hunted in the country (www.eagri.cz), and are widely harvested (Macháček, Dvořák et al., 2014).

\section{Sika Deer Ecology in the Czech Republic}

\section{Habitats and Resources}

Sika deer's preferred habitat consists of edges of forested areas with a dense understory, but they adapt well to a variety of other habitats (Nowak, 1999; Smith and Xie, 2009) and can be found at a broad range of elevations, from sea level to about $3.000 \mathrm{~m}$ a.s.l. (Ohdachi, Ishibashi et al., 2009). Sika deer are generalist intermediate feeders (Hofmann, 1988), as they can both graze and browse; their diet is highly adaptable and can vary according to the habitat or the geographic location (Takatsuki, 1991). When facing food shortage, sika start feeding on low-quality alternatives such as fallen leaves, bark, twigs, and even unpalatable plants (Takatsuki and Ikeda, 1993; Takahashi and Kaji, 2001; Miyaki and Koichi, 2004). As for the Czech Republic, sixty per cent of the country's landscape is flat or distributed at a low altitude (200-600 $\mathrm{m}$ a.s.l.), and about thirty-four percent of its surface is covered in forests (Chytrý, 2012).

\section{Presence of Predators}

In the Czech Republic, large carnivores such as wolves (Canis lupus) have recently started spreading (Kutal et al., 2018; Lososová et al., 2019), while the Eurasian lynx (Lynx lynx) -after a temporary recovery due to both human driven and natural reoccupation of the landscape- is currently endangered by poaching (Červený, Koubek et al., 2002; Červený, Krojerová-Prokešová et al., 2019). In addition, an exiguous number of brown bears (Ursus arctos) trespasses from Slovakia and seldom settles in the country (Červený, Bartošová et al., 2004; Rigg and Adamec, 2007). Data on wolf predation on sika deer in the Czech Republic are not available, but the predator is known to feed on species of comparable size in other areas of Europe, such as countries of the former Soviet Union (Jędrzejewski, Jędrzejewska et al., 1992).

\section{Other Sources of Mortality}

Wildlife-vehicle collision (WVC) is a growing problem for several countries across the world as it interests a great variety of species (Forman, Sperling et al., 2003; Ascensão, Clevenger et al., 2013), affects population density and survival (Lao, Zhang et al., 2011), and complicates the management and conservation of motile wildlife (Neumann, Ericsson et al., 2012). Even if WVCs occur across the whole country ("Animal-Vehicle Collision”, http://srazenazver.cz/en/), in the Czech Republic there is no detailed analysis of the affected species, being it included neither in the Czech Traffic Police database (Kušta, Keken et al., 2014), nor (specifically for sika deer) in the online platform "Animal-Vehicle Collision". The lack of information about ungulates related WVC represents a flaw in the management of these species. Thus, it would be important to systematically collect these data because, when the number of ungulates increases and the main source of data on their population is represented solely by the hunting bags, data on WVC may represent an important and inexpensive complementary data source (Neumann et al., 2020). Along with a pervasive road infrastructure, the Czech Republic also contains one of the densest railway infrastructures of Europe (Keken, Kušta et al., 2016; Keken and Kušta, 2017) that represents a further possible cause of wildlife mortality (S.C.V., 1996; Dorsey, Olsson et al., 2015; Santos, Carvalho et al., 2017), especially for the ungulates (Santos, Carvalho et al., 2017). However, its impact can be considered relatively low on species with high density, a fast reproduction rate, and that are not endangered (van der Grift and Kuijsters 1998, van der Grift 1999). 


\section{Accuracy of Hunting Plans in the Czech Republic}

Whether hunting is a sufficient strategy for controlling populations of ungulates in the Northern hemisphere has been widely debated (Hagen, Haydn et al., 2018). Nevertheless, indirect proxies of abundance, such as hunting bags, are currently used as a reliable method by $64 \%$ of European countries (Neumann, Widemo et al., 2020). In the Czech Republic, hunt control records are known from the first half of the $9^{\text {th }}$ century and Czech game management statistics have been kept since 1966. Moreover, starting from 1992, hunters are also obliged to declare and seal the culled animals, practice that guarantees not only reliable data, but also an inspection of the health condition of the game and, consequently, good quality venison (Šeplavý, Růžička et al., 2015). In spite of these precautions, errors and inaccuracy in hunting plans for large herbivore game are common (Plhal and Kamler, 2013; Dvořák and Palyzová, 2016). In their study, Plhal and Kamler (2013) ascribed these mistakes to miscalculations of actual game density due to use of the unfitting method of direct counting. Being true that this method offers a wide range of information on the observed animals (e.g., gender, age, health conditions, etc.) it is also true that an under-evaluation of the abundance is frequent (Plhal and Kamler, 2013).

The main aim of this study is to estimate the trend of the sika deer culled in the subpopulations of the Czech Republic, taking into account the hunting bags and the environmental features for each subpopulation area, along with other possible sources of mortality in order to highlight limits and obstacles to the management of the species.

\section{MATERIALS AND METHODS}

In this study, we used the official hunting bag statistics from the Ministry of Agriculture of the Czech Republic from the year 1994 to the year 2018. Our data included the number of female, male and young (up to 1 year of age) sika deer harvested each year in each of the different districts of the country in the totality of hunting areas. Although there are at least two subspecies (i.e., C. $n$. hortulorum and $C$. n. nippon), the statistics available do not distinguish between them.

According to Barančeková, Krojerová-Prokešová et al. (2012) there are currently two subpopulations of sika recognised in the Czech Republic, one in the West-Bohemia and one in the CentralEastern Bouzovsko area. Using GPS telemetry, an

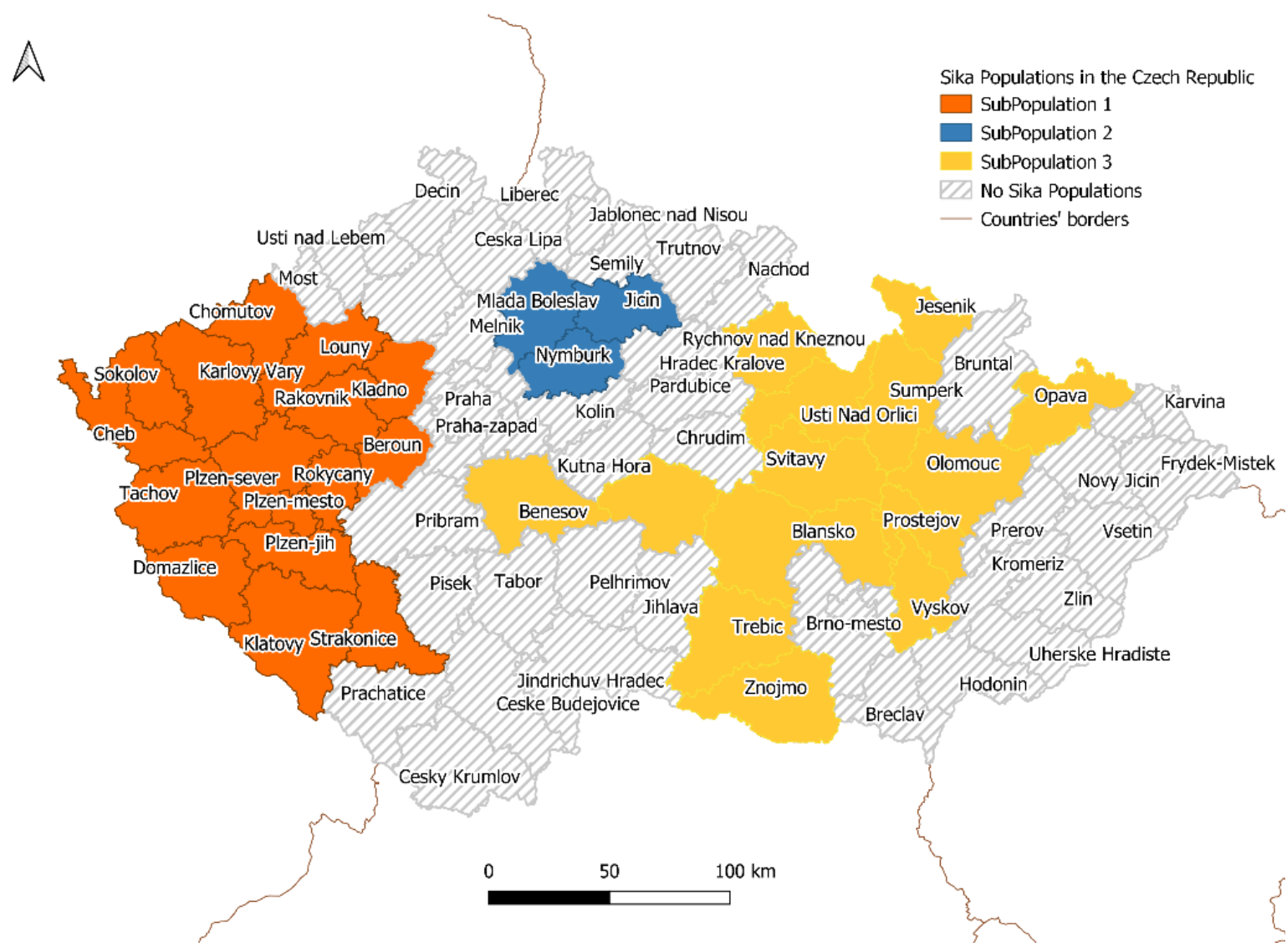

1: The three subpopulations of sika deer identified for the Czech Republic. Only the districts with at least three culled sika deer for three consecutive years are shown. This measure was taken in order to avoid overestimating the range by including also passages or temporary districts. 
investigation of the sika deer's spatial distribution conducted in the country using the minimum convex polygon method revealed that the mean home range size (obtained from subadult and adult males) was 3620 ha (Dvořák, Barták et al., 2014). Such a size exceeds the mean area of hunting ground in many parts across the country. Besides, from studies realized elsewhere, we know that some individual sika may be classified as nomadic and have long-distance movements across the landscape associated or un-associated with seasons (Kalb, Bowman et al., 2013; Takafumi, Kamil et al., 2017). Thus, we used data from all areas where the sika deer harvest has been recorded. We divided the Czech population of sika deer in three subpopulations according to the area of culling (Fig. 1), taking into consideration both the forest distribution and the inter-district connections, and separating them on the base of districts borders and presence of barriers (e.g., railways, highways, rivers, cities and other large urbanized areas). We analysed the environmental features of the Czech landscape (i.e., water elements, urban fabrics and vegetation, including coniferous, mixed and deciduous forests) during our study timeframe with the support of Google Earth layers (roads and railways), and Corine
Land Cover (C.L.C.) shape files (Fig. 2). The analysis of the C.L.C. from 2002 and 2012 did not highlight any relevant modification of neither the natural nor the urban environments during the years, therefore we decided to take into consideration only the most recent one (Fig. 2). Using G.I.S. software (QGIS 3.8.1), we estimated the non-artificial vegetation cover (i.e., arable lands, permanent crops, pastures, heterogeneous agricultural crops, forests and seminatural areas, shrubs and/or herbaceous vegetation association) of the subpopulations ranges in order to highlight similarities and differences among the regions investigated.

Being our database vast and susceptible to errors during the transcription of data, we checked for extreme values in the database via the identification of outliers. After having organised the values in numerical order, we extrapolated the median and the quartiles. Then, we calculated the interquartile range and multiplied it for 1.5 (inner fence outliers) and 3 (outer fence outliers). The values that were higher or lower than the results of our multiplications were excluded from the analysis (Tab. I). Furthermore, we estimated the mean annual increase of sika culled in the three different subpopulations according to the equation

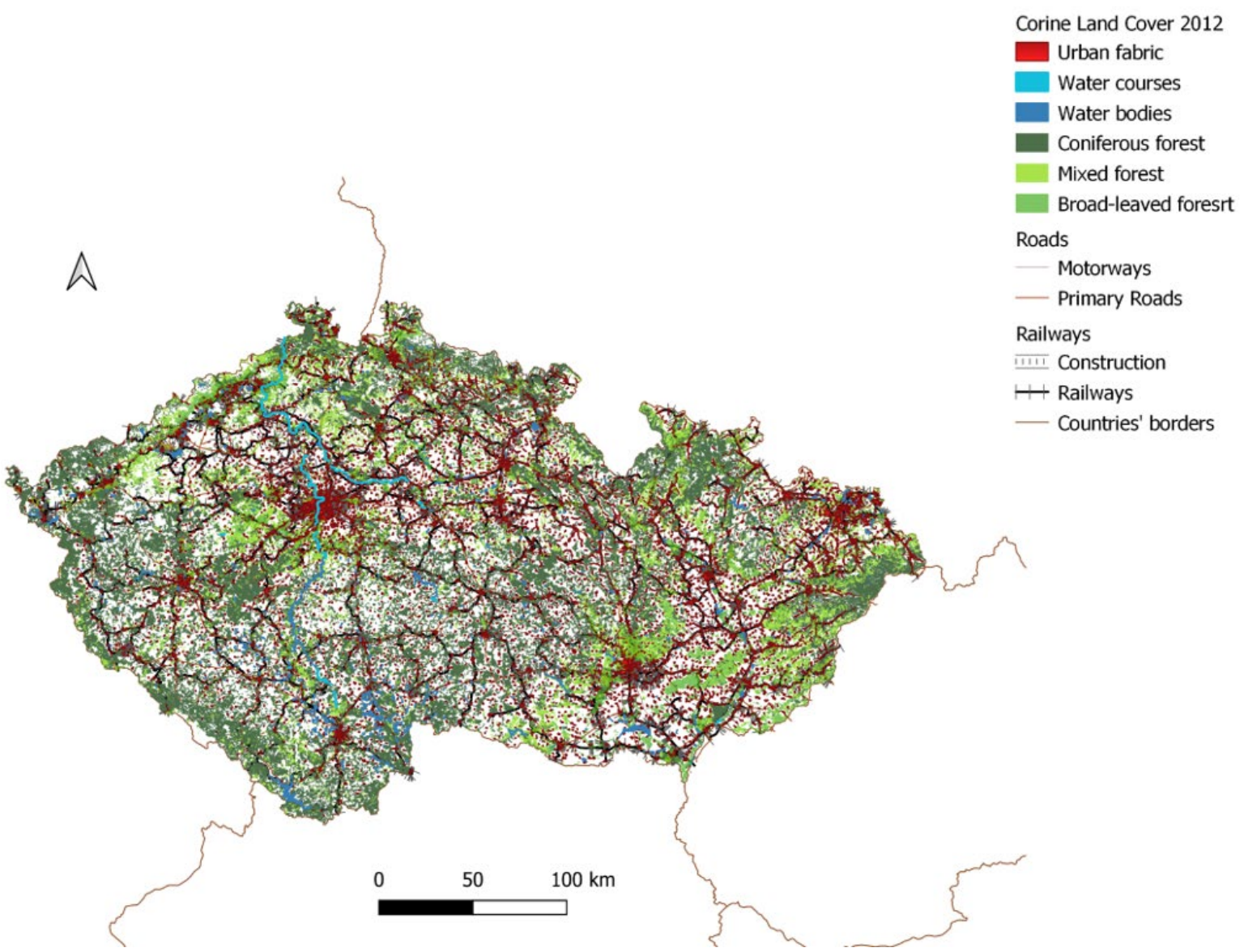

2: Types of land cover in the Czech Republic considered in this study (data obtained from Corine Land Cover 2012). The map also shows the web of roads and railways of the country (data obtained from Google Earth). 
A.a. $i=\left(\frac{x}{y}\right)^{\frac{1}{n}}-1$,

where

$X$.....number of the deer culled in that subpopulation in 2018,

$y$.....the number of deer culled in that subpopulation in 1994, and

$n$.....the number of years in the considered timeframe (Tab. I).

Last, we transformed our results in percentage values.

In order to estimate the role of other sources of mortality on the management of sika deer in the Czech Republic, we searched for data on WVC and predation. We used the Web of Science, Scopus and Google Scholar databases (Keywords: "sika deer AND Czech Republic AND mortality" and "Sika deer AND Czech Republic AND predation" and "Sika deer AND Czech Republic AND traffic collision”) but we were not able to find numeric data on these matters. Last, to take into account the presence of wolf populations as a possible source of sika deer mortality, we overlapped the most recent map of wolf packs distribution across the country (2019) with the subpopulations map (Fig. 3) in order to estimate the level of overlapping with every subpopulation and make predictions for the future.

\section{RESULTS}

The analyses of the sika deer culled in the three culling subpopulations showed very different trends (Fig. 4). Over the period between 1994 and 2018, the average annual percentages of culling were of $7.4 \%$ (SP1), 1\% (SP2), and 3.7\% (SP3).

The SP1, located in the West of the country, resulted to be the second biggest subpopulation in terms of spatial extension (occupying an area of $16.243 \mathrm{~km}^{2}$ ) and the first in terms of the number of culled deer. Almost the totality of the sika harvested during the years in the country was, in fact, represented by animals culled in these districts (Fig. 5). The SP1 was also the subpopulation in which the culled deer incremented the most. The SP2, which occupied a small number of districts in the Northern part of the country (covering an area of about $2.760 \mathrm{~km}^{2}$ ) had, instead, the lowest increase. The third and last subpopulation SP3, situated in the Eastern part of the Czech Republic (covering an area of about $18.279 \mathrm{~km}^{2}$ ), ranked second for the total number of overall culled deer. Even though all three areas were covered by vegetation for the almost totality, the vegetal composition was different among the ranges (Fig. 6). The SP2, specifically, was the one with the highest level of arable lands and the one with the smallest percentage of forest cover (Fig. 6), while the SP1 was the one with the highest presence of forested lands and the smallest of arable ones. Even though all the subpopulations presented
I: Number of sika deer culled per year in each subpopulation

\begin{tabular}{|c|c|c|c|}
\hline & SP1 & SP2 & SP3 \\
\hline 1994 & 2829 & 60 & 524 \\
\hline 1995 & 3158 & 50 & 627 \\
\hline 1996 & 3087 & 46 & 725 \\
\hline 1997 & - & 54 & 719 \\
\hline 1998 & 5397 & 75 & 634 \\
\hline 1999 & 4241 & 79 & 620 \\
\hline 2000 & 5053 & 59 & 747 \\
\hline 2001 & 5695 & 75 & 742 \\
\hline 2002 & 5106 & - & 680 \\
\hline 2003 & 6390 & 68 & 552 \\
\hline 2004 & 6180 & 72 & 566 \\
\hline 2005 & 6346 & 67 & 563 \\
\hline 2006 & 6123 & 65 & 516 \\
\hline 2007 & 7222 & 82 & 635 \\
\hline 2008 & 8312 & 74 & 695 \\
\hline 2009 & 8686 & 64 & 782 \\
\hline 2010 & 10061 & 69 & 879 \\
\hline 2011 & 9929 & 56 & 884 \\
\hline 2012 & 11301 & - & 1137 \\
\hline 2013 & 11813 & 60 & 966 \\
\hline 2014 & 12959 & 79 & 980 \\
\hline 2015 & 13411 & 60 & 1070 \\
\hline 2016 & 14876 & 66 & 1202 \\
\hline 2017 & 15750 & 94 & 1262 \\
\hline 2018 & 16993 & 76 & 1299 \\
\hline
\end{tabular}

a certain degree of overlapping or proximity with observations of wolves, the SP2 was the one with the most overlapping range, while SP3 had the least, with only few wolf observations (wolf occurrence: Lososová et al., 2019) (Fig. 3).

\section{DISCUSSION}

In this study, we wanted to estimate the growth trends of the number of culled sika deer in the culling subpopulations present in the Czech Republic. To do so, we took into account the hunting bags and the environmental features of the areas occupied by the different subpopulations, to remark existing limits to a successful management of the species. Also, we investigated other sources of mortality and future perspectives for the management of this species.

As Apollonio et al. (2010) have thoroughly discussed, the management of ungulates is a complex matter which should cover several issues, such as the damages that these species can cause to 


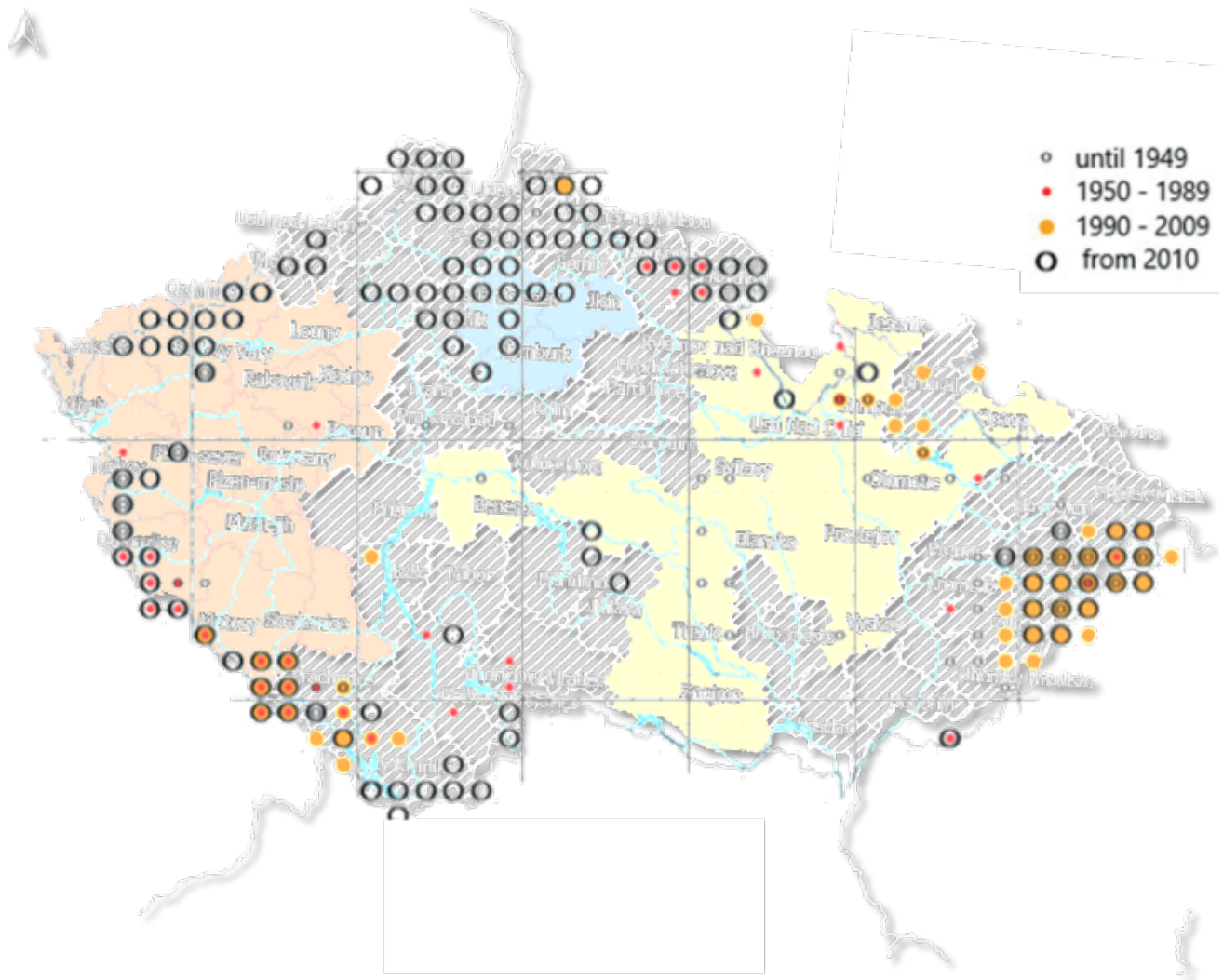

3: Overlapping map of wolf occurrence and culled sika deer subpopulations. Data on wolf occurrence was obtained from (Lososová et al., 2019).

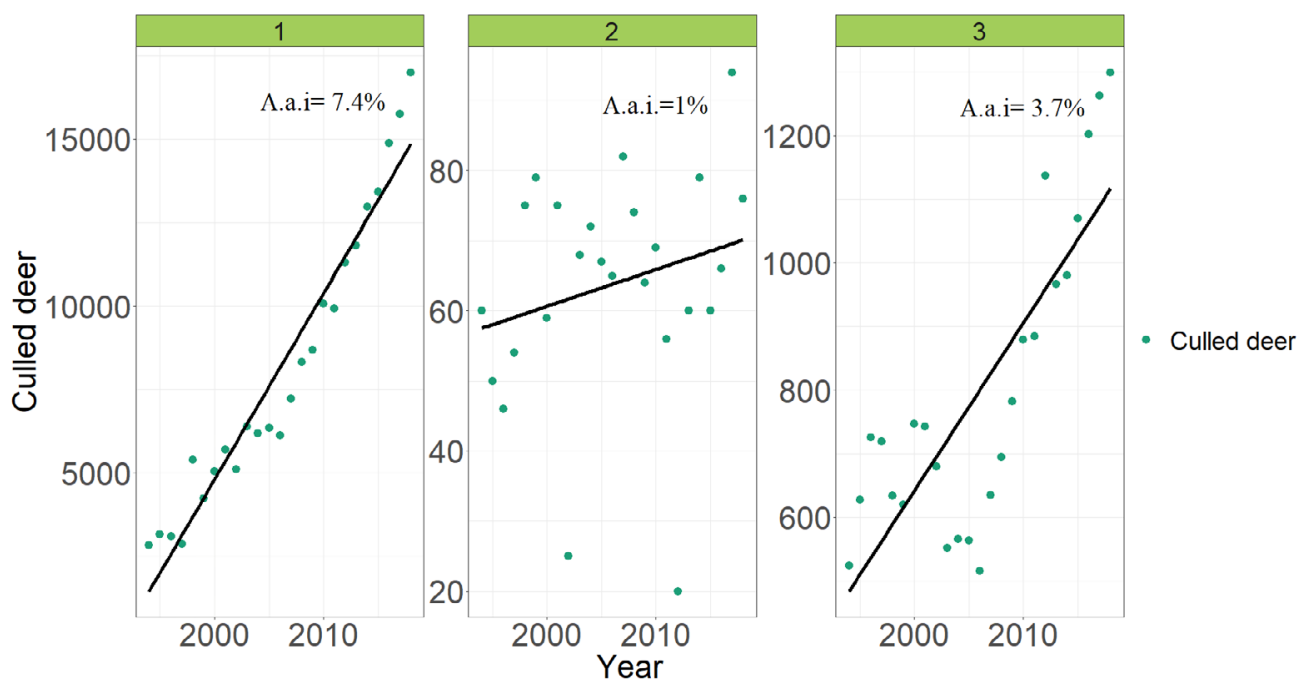

4: Trends of sika deer culled in the Czech Republic in the three subpopulations (1994-2018) and annual average percentage of increase (A.a.i)

the environment, the role of ungulates as driver of habitat change, and the occurrence of road traffic incidents involving ungulates (Apollonio, Andersen et al., 2010). Being the sika deer also present as an alien species in the Czech Republic, their monitoring, management, and hunting season and strategy should be faultlessly planned and carried out. In the last five decades, the number of sika deer in the Czech Republic has increased exponentially, which seems to suggest that the numbers are underestimated and, hence, the number of culled deer is not enough to maintain the population stable and safeguard the native species and the local vegetation. Thus, over the whole time interval (i.e., 25 years), the number of culled sika deer in the different areas of occupancy revealed an alarming 


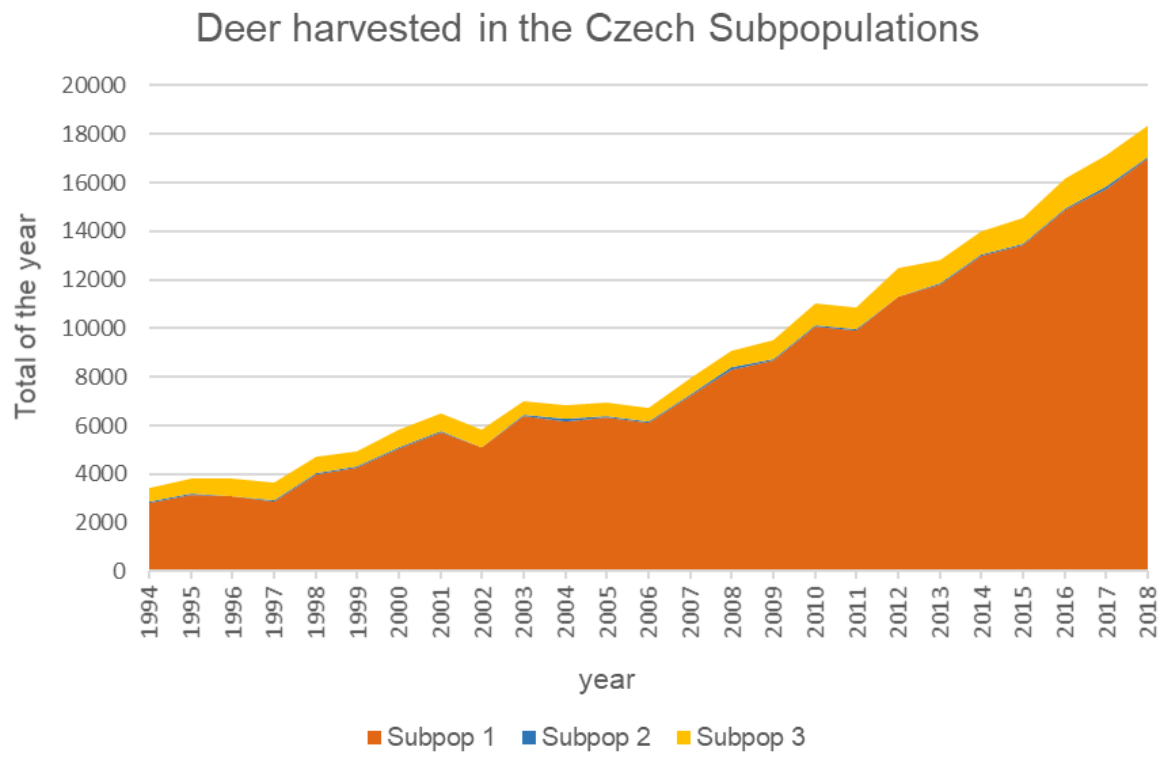

5: Sika deer culled in the Czech Republic by year and by subpopulation (1994-2018)

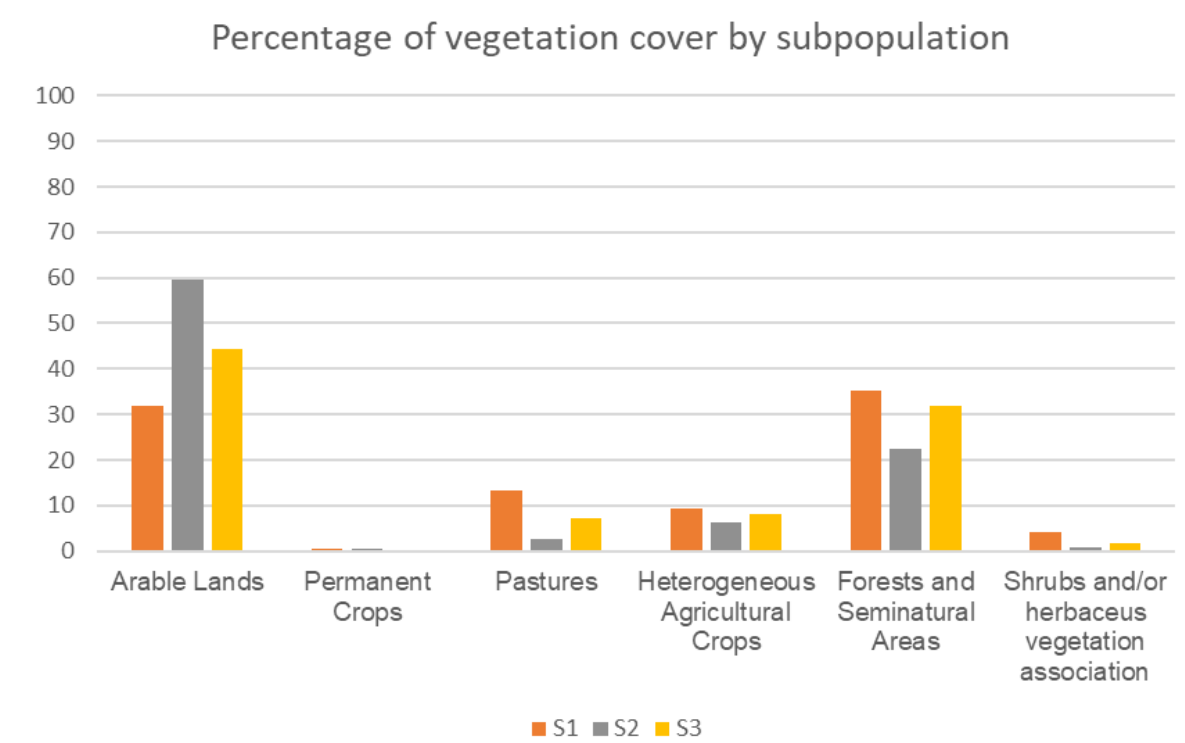

6: Percentage of land covered by different types of non-artificial vegetation in the three subpopulations areas

mean annual increase between 1 and 7.4\%. The issue seems to be particularly relevant for the subpopulations of sika living in the East and in the West of the country, while the one in the centre, which is also the smallest one, appears to be rather stable.

Reasons for the different harvesting trends shown in the three areas and for the different success of the management strategies could be found in the characteristics of the occupied areas, mostly with regards to parameters of largeness and vegetation cover. Among the three subpopulations, in fact, SP2 seems to be the easiest to manage in terms of counting and monitoring of deer (having a rather smaller area of occupancy) and, consequently, in planning hunting seasons. The scarcity of forested area in favour of an abundance of arable lands (Fig. 6) may also make it more difficult for the deer to hide, both during the operations of counting and during the hunting season. Conversely, SP1 and SP3 are spread across relatively larger areas hosting, as suggested by the high number of culled deer, a significantly denser deer population, which may make the monitoring process more susceptible to errors and miscounting. SP1 also presents a higher percentage of forested areas (Fig. 4) and close proximity to the Šumava National Park. Moreover, a denser population may lessen the effects of other sources of mortality such as traffic collisions and railway incidents. Unfortunately, for these two 
factors, it is not possible to estimate their impact on sika deer due to the lack of data on the species. Even though data suitable to estimate the effects of wolf predation on the species are not available, we consider it to be an important asset for the future management due to the wolves spreading across the country in recent times (Lososová et al., 2019). Considering the relatively small extension of the area and the limited number of sika deer deduced by the stable hunting bags, the presence of the wolf packs may represent, in the future, an additional factor to keep the deer population under control in this area and help making up for underestimated culling rates (Ripple and Beschta, 2012; Ripple, Estes et al., 2014). Nevertheless, the need of properly planned counts and of a better-aimed management strategy, including the collection of complementary data (e.g., predation, WVC) has been proven to be essential and unavoidable.

\section{CONCLUSION}

The Czech Republic hosts a high, permanently increasing, number of sika deer. The hunting pressure and the hunting control exerted following the current system and practice are not sufficient to keep the population stable and contained, especially in the Western part of the country. Sika are well-known for the significant impacts that their browsing, debarking, and grazing activities have on ecosystems and for the effects that the hybridization with red deer has on the latter species' genetics and conservation. Moreover, large herbivores, when in high density, can also become a threat to the safety of citizen due to the increasing number of traffic-related accidents. Considering the well-documented rising number of sika deer in the country and the damages to both flora and fauna, and taking into account both the low efficiency of the management strategies so far carried out and the low impact of the exiguous number of predators currently living in the country, we conclude that investing more resources to improve the quality of hunting plans, as well as to implement the management strategies, seems to be an impelling need for the Czech Republic, especially in the Western part of the country.

\section{Acknowledgements}

We are grateful to Dr. Martin Žižka from the Ministry of Agriculture of the Czech Republic and to Dr. Kamil Turek from the Forest Management Institute (ÚHUL) of Frýdek-Místek for providing us with detailed data. This study was supported by the Internal Grant Agency of the Faculty of Forestry and Wood Sciences (Czech University of Life Sciences) [project A_19_23], and by the Ministry of Agriculture of the Czech Republic [Institutional Support MZE-RO0718].

\section{REFERENCES}

APOLLONIO, M., ANDERSEN, R. and PUTMAN, R. 2010. European ungulates and their management in the $21^{\text {st }}$ century. Cambridge University Press.

ASCENSÃO, F., CLEVENGER, A., SANTOS-REIS, M., URBANO, P. and JACKSON, N. 2013. Wildlife-vehicle collision mitigation: Is partial fencing the answer? An agent-based model approach. Ecological Modelling, 257: 36-43.

BARANČEKOVÁ, M., KROJEROVÁ-PROKEŠOVÁ, J., VOLOSHINA, I., MYSLENKOV, A., KAWATA, Y., OSHIDA, T., LAMKA, J. and KOUBEK, P. 2012. The origin and genetic variability of the Czech sika deer population. Ecological research, 27(6): 991-1003.

BARTOŠ, L. 1981. Hybridization between red and sika deer. I: Craniological analysis. Zoologischer Anzeiger, 207: 260-270.

BARTOŠ, L. 1993. Cluster analysis of red and sika deer phenotypes. In: OHTAISHI, N. and SHENG, H.-I. (Eds.). Deer of China: biology and management. Amsterdam, Oxford, New York, Tokyo: Elsevier, pp. 15-21.

BARTOŠ, L. 2009. Sika deer in continental Europe. In: MCCULLOUGH, D. R., TAKATSUKI, S. and KAJI, K. (Eds.). Sika Deer: Biology and management of native and introduced populations. Tokyo, Berlin, Heidelberg, New York: Springer, pp. 573-594.

ČERVENÝ, J., BARTOŠOVÁ, D., ANDĚRA, M. and KOUBEK, P. 2004. Recent distribution of the brown bear (Ursus arctos) in the Czech Republic [in Czech: Současné rozšíření medvěda hnědého (Ursus arctos) v České republice]. Lynx, 35: 19-26.

ČERVENÝ, J., KOUBEK, P. and BUFKA, L. 2002. Eurasian Lynx (Lynx Lynx) and its Chance for Survival in Central Europe: The Case of the Czech Republic. Acta Zoologica Lituanica, 12(4): 428-432. 
ČERVENÝ, J., KROJEROVÁ-PROKEŠOVÁ, J., KUŠTA, T. and KOUBEK, P. 2019. The change in the attitudes of Czech hunters towards Eurasian lynx: Is poaching restricting lynx population growth? Journal for nature conservation, 47: 28-37.

CHYTRÝ, M. 2012. Vegetation of the Czech Republic: diversity, ecology, history and dynamics. Preslia, 84(3): 427-504.

DORSEY, B., OLSSON, M. and REW, L. J. 2015. Ecological effects of railways on wildlife. Handbook of road ecology. John Wiley \& Sons, pp. 219-227.

DVOŘÁK, J. and PALYZOVÁ, L. 2016. Analysis of the Development and Spatial Distribution of Sika Deer (Cervus nippon) Populations on the Territory of the Czech Republic. Acta Universitatis Agriculturae et Silviculturae Mendelianae Brunensis, 64(5): 1507-1515.

DVOŘÁK, S., BARTÁK, V., MACHÁČEK, Z. and MATĚJÜ, J. 2014. Home range size and spatio-temporal dynamics of male sika deer (Cervus nippon; Cervidae, Artiodactyla) in an introduced population. Journal of Vertebrate Biology, 63(2): 103-115.

FORMAN, R. T., SPERLING, D., BISSONETTE, J. A., CLEVENGER, A. P., CUTSHALL, C. D., DALE, V. H., FAHRIG, L., FRANCE, L. R., HEANUE, K. and GOLDMAN, C. R. 2003. Road ecology: science and solutions. Island press.

GENOVESI, P., BACHER, S., KOBELT, M., PASCAL, M. and SCALERA, R. 2009. Alien mammals of Europe. In: Handbook of alien species in Europe. Springer, pp. 119-128.

HAGEN, R., HAYDN, A. and SUCHANT, R. 2018. Estimating red deer (Cervus elaphus) population size in the Southern Black Forest: the role of hunting in population control. European Journal of Wildlife Research, 64(4): 42

HOFMANN, R. R. 1988. Aspects of digestive physiology in ruminants. In: DOBSON, A. and DOBSON, M. J. (Eds.). Proceedings of a Satellite Symposium of the $30^{\text {th }}$ International Congress of the International Union of Physiological Sciences. Ithaca, New York: Cornell University Press.

JĘDRZEJEWSKI, W., JĘDRZEJEWSKA, B., OKARMA, H. and RUPRECHT, A. L. 1992. Wolf predation and snow cover as mortality factors in the ungulate community of the Bialowieża National Park, Poland. Oecologia, 90(1): 27-36.

KALB, D. M., BOWMAN, J. L. and EYLER, T. B. 2013. Dispersal and home-range dynamics of exotic, male sika deer in Maryland. Wildlife Research, 40(4): 328-335.

KEKEN, Z. and KUŠTA, T. 2017. Railway ecology-experiences and examples in the Czech Republic. In: Railway Ecology. Cham: Springer, pp. 247-260.

KEKEN, Z., KUŠTA, T., LANGER, P. and SKALOŠ, J. 2016. Landscape structural changes between 1950 and 2012 and their role in wildlife-vehicle collisions in the Czech Republic. Land Use Policy, 59: 543-556.

KETTUNEN, M., GENOVESI, P., GOLLASCH, S., PAGAD, S., STARFINGER, U., TEN BRINK, P. and SHINE, C. 2009. Technical support to EU strategy on invasive species (IAS) - Recommendations on policy options to control the negative impacts of IAS on biodiversity in Europe and the EU. Final report for the European Commission. Brussels: Institute for European Environmental Policy (IEEP).

KOKEŠ, O. 1970. Asijští jeleni na území Československa. Ochrana fauny, 4: 158-161.

KROJEROVÁ-PROKEŠOVÁ, J., BARANČEKOVÁ, M., KAWATA, Y., OSHIDA, T., IGOTA, H. and KOUBEK, P. 2017. Genetic differentiation between introduced Central European sika and source populations in Japan: effects of isolation and demographic events. Biological Invasions, 19(7): 2125-2141.

KUŠTA, T., KEKEN, Z., BARTÁK, V., HOLÁ, M., JEŽEK, M., HART, V. and HANZAL, V. 2014. The mortality patterns of wildlife-vehicle collisions in the Czech Republic. North-Western Journal of Zoology, 10(2): 393-399.

LAO, Y., ZHANG, G., WU, Y.-J. and WANG, Y. 2011. Modeling animal-vehicle collisions considering animal-vehicle interactions. Accident Analysis \& Prevention, 43(6): 1991-1998.

LOSOSOVÁ, J., KOUŘILOVÁ, J. and DOHNALOVÁ, A. 2019. Increasing conflict between predator protection and pastoral farming in the Czech Republic. Trames Journal of the Humanities \& Social Sciences, 23(4): 381.

MACHÁČEK, Z., DVOŘÁK, S., JEŽEK, M. and ZAHRADNíK, D. 2014. Impact of interspecific relations between native red deer (Cervus elaphus) and introduced sika deer (Cervus nippon) on their rutting season in the Doupovské hory Mts. Journal of forest science, 60(7): 272-280.

MCNEELY, J. A. et al. 2001. Global strategy on invasive alien species. Gland Switzerland and Cambridge: IUCN.

MIYAKI, M. and KOICHI, K. 2004. Summer forage biomass and the importance of litterfall for a high-density sika deer population. Ecological Research, 19(4): 405-409.

MOONEY, H. A. et al. 2005. Invasive alien species: a new synthesis. Island press.

NENTWIG, W., KÜHNEL, E. and BACHER, S. 2010. A generic impact-scoring system applied to alien mammals in Europe. Conservation Biology, 24(1): 302-311. 
NEUMANN, W., ERICSSON, G., DETTKI, H., BUNNEFELD, N., KEUlER, N. S., HELMERS, D. P. and RADELOFF, V. C. 2012. Difference in spatiotemporal patterns of wildlife road-crossings and wildlifevehicle collisions. Biological Conservation, 145(1): 70-78.

NEUMANN, W., WIDEMO, F., SINGH, N. J., SEILER, A. and CROMSIGT, J. P. 2020. Strength of correlation between wildlife collision data and hunting bags varies among ungulate species and with management scale. European Journal of Wildlife Research, 66(6): 86.

NOWAK, R. W. 1999. Walker's Mammals of the World. Baltimore: Johns Hopkins University.

OHDACHI, S. D., ISHIBASHI, Y., IWASA, M. A., SAITOH, T. and SELLERS, S. B. 2009. The wild mammals of Japan. Kyoto: Shoukadoh Book Sellers Kyoto.

PLHAL, R. and KAMLER, J. 2013. Analysis of accuracy of hunting plan in the Czech Republic. Acta Universitatis Agriculturae et Silviculturae Mendelianae Brunensis, 60(3): 165-172.

RIGG, R. and ADAMEC, M. 2007. Status, ecology and management of the brown bear (Ursus arctos) in Slovakia. Liptovský Hrádok: Slovak Wildlife Society.

RIPPLE, W. J. and BESCHTA, R. L. 2012. Large predators limit herbivore densities in northern forest ecosystems. European Journal of Wildlife Research, 58(4): 733-742.

RIPPLE, W. J., ESTES, J. A., BESCHTA, R. L., WILMERS, C. C., RITCHIE, E. G., HEBBLEWHITE, M., BERGER, J., ELMHAGEN, B., LETNIC, M. and NELSON, M. P. 2014. Status and ecological effects of the world's largest carnivores. Science, 343(6167): 1241484.

ROY, D. B. and HULME, P. E. 2008. Delivering Alien Invasive Species Inventories for Europe: DAISIE as a tool for addressing biological invasions. In: NEOBIOTA: Towards a Synthesis. $5^{\text {th }}$ European Conference on Biological Invasions. Prague, 23-26 th September 2008.

SCV. 1996. Mortalidad de vertebrados en lineas de ferrocarril. Documentos Técnicos de Conservación SCV 1. Sociedad para la Conservación deVertebrados, Madrid.

SANTOS, S. M., CARVALHO, F. and MIRA, A. 2017. Current knowledge on wildlife mortality in railways. In: Railway ecology. Cham: Springer, pp. 11-22.

ŠEPLAVÝ, P., RŮŽIČKA, J. and PONDĚLÍČEK, J. 2015. Game Management in the Czech Republic. Ministry of Agriculture of Czech Republic.

SMITH, A. and XIE, Y. 2009. A guide to the mammals of China. Hunan Education Press.

TAKAFUMI, H., KAMII, T., MURAI, T., YOSHIDA, R., SATO, A., TACHIKI, Y., AKAMATSU, R. and YOSHIDA, T. 2017. Seasonal and year-round use of the Kushiro Wetland, Hokkaido, Japan by sika deer (Cervus nippon yesoensis). PeerJ, 5: e3869.

TAKAHASHI, H. and KAJI, K. 2001. Fallen leaves and unpalatable plants as alternative foods for sika deer under food limitation. Ecological Research, 16(2): 257-262.

TAKATSUKI, S. 1991. Feeding ecology of herbivorous mammals with special reference to cervids. In: ASAHI, M. and KAWAMICHI, T. (Eds.). Modern mammalogy. Tokyo: Asakura, pp. 119-144.

TAKATSUKI, S. and IKEDA, S. 1993. Botanical and chemical composition of rumen contents of Sika deer on Mt Goyo, northern Japan. Ecological Research, 8(1): 57-64.

VAN DER GRIFT, E. 1999. Mammals and railroads: impacts and management implications. Lutra, 42 : 77-98.

VAN DER GRIFT, E. A. and KUIJSTERS, R. 1998. Mitigation measures to reduce habitat fragmentation by railway lines in the Netherlands. In: International Conference on Wildlife Ecology and Transportation (ICOWET 1998). Florida Department of Transportation, US Department of Transportation, US Forest Service and Defenders of Wildlife.

VAVRUNĚK, J. 1977. Breeding of red deer in West-Bohemian region. Textbook Sci. For. Inst. VŠZ Prague, 20: 97-115. 